\title{
THE NUTRITIONAL BALANCE OF EARLY LACTATION DAIRY COWS GRAZING IN INTENSIVE SILVOPASTORAL SYSTEMS
}

\author{
EQUILÍBRIO NUTRICIONAL DAS VACAS LEITEIRAS EM ALTA \\ PRODUÇÃO PASTANDO EM SISTEMAS SILVIPASTORIS INTENSIVOS
}

\author{
Elisa Sierra Montoya ${ }^{1 *}$ \\ Julian David Chará ${ }^{2}$ \\ Rolando Barahona-Rosales ${ }^{1}$ \\ 1Universidade Nacional de Colômbia, Medellín, Colômbia \\ ${ }^{2}$ Centro para la Investigación en Sistemas Sostenibles de Producción Agropecuaria - CIPAV, Cali, Colômbia \\ *Corresponding author - elsierramo@unal.edu.co
}

\begin{abstract}
A study was carried out to estimate the balance of metabolizable protein (MP), metabolizable energy (ME), calcium, and phosphorus in 12 recently calved (RC) and early lactation (EL, 42 - 50 days after calving) Gyr x Holstein dairy cows grazing in a Leucaena leucocephala and Cynodon plectostachyus intensive silvopastoral system (ISS) and receiving energy and protein supplementation. Dry matter (DM) availability from the grazing paddocks, nutrients offered and their balance were estimated. On average, the available forage DM per animal.day ${ }^{-1}$ was $44.7 \mathrm{~kg}$ for C. plectostachyus and $11.8 \mathrm{~kg}$ for $L$. leucocephala. EL cows had greater requirements of MP, ME, and minerals than RC cows. In RC cows, ME, MP, and mineral requirements were supplied by the total diet, while EL cows exhibited a negative energy balance. For both RC and EL cows, ME was the limiting dietary factor, whereas MP and P were found to be in excess. If cows were only to receive ISS forages with no supplementation, estimated daily milk yield would be 10 and 12 litters for RC and EL cows, respectively. Under tropical conditions, based on ISS forage intake, RC and EL cows can meet most of their ME, MP, calcium, and phosphorous requirements.
\end{abstract}

Keywords: energy balance; Leucaena leucocephala; nutrient requirements; phosphorus balance; protein balance.

\section{Resumo}

Um estudo foi realizado para estimar o equilíbrio de proteína metabolizável (PM), energia metabolizável (EM), cálcio e fósforo em 12 vacas Gyr x Holandesa recém-paridas (RP) e início da lactação (IL, 42-50 dias após o parto), pastando em um sistema silvipastoril intensivo (SSI) com Leucaena leucocephala e Cynodon plectostachyus e recebendo suplementação energética e protéica. A disponibilidade da matéria seca (MS) dos piquetes de pastagem, nutrientes oferecidos e seu equilíbrio foram estimados. A oferta de forragem média (kg MS) por animal.dia ${ }^{-1}$ foi 44,7 de C. plectostachyus e 11,8 de L. leucocephala. Vacas IL tiveram maiores exigências da MP, ME e minerais que vacas RP. Em vacas RP, requisitos da EM, PM e minerais foram fornecidos pela dieta total, enquanto vacas IL exibiram um balanço energético negativo. Tanto para vacas de RP e IL, EM foi o fator limitante da 
dieta, enquanto que PM e P foram encontrados em excesso. Se as vacas recebessem apenas forragem SSI sem suplementação, a produção de leite diária estimada seria de 10 e 12 litros para as vacas RP e IL. Em condições tropicais, com base no consumo de forragem em SSI, vacas RP e IL podem ter a maioria das suas necessidades de EM, PM, cálcio e fósforo atendidas.

Palavras-chave: balanço de energia; balanço de fósforo; balanço da proteína; Leucaena leucocephala; necessidades de nutrientes.

Receveid on March 23 $3^{\text {th }}, 2016$

Accepted on February $16^{\text {th }}, 2017$

\section{Introduction}

A balanced nutrition is required for adequate productive and reproductive performance of dairy cows ${ }^{(1)}$. Due to their high productivity, the nutritional requirements of cows in specialized tropical dairy farms are difficult to meet. Before calving, there is a reduction in dry matter intake (DMI) and as the birth event approaches, DMI reduces even further ${ }^{(1)}$. At parturition, after colostrum production stops, milk is produced in high volumes during the period known as early lactation, which accounts for the high nutritional requirements reported for dairy cows represented in a high dietary demand of protein, energy and minerals.

Under tropical conditions, livestock production systems are commonly based in grazing of native pastures, characterized by poor quality and limited forage availability during the dry season ${ }^{(2)}$. Under stressful environmental conditions such as reduced precipitation, high ambient temperatures and humidity, tropical forages accumulate structural carbohydrates or plant cell walls, which limits their digestibility, which in few instances is greater than $55 \%$, and voluntary $\mathrm{DMI}^{(3,4)}$.

Estimation of the nutrient requirements for maintenance, pregnancy, and lactation and their difference (balance) with dietary available nutrients is a good practice that can contribute to enhance the reproductive and productive performance of animals. Energy availability is of great importance to the nutrition of the adult $\operatorname{cow}^{(1,3)}$, and affects reproductive performance and milk production during early lactation. This is of particular importance under tropical conditions as energy availability is limited due to high structural content of most forages ${ }^{(3)}$. Likewise, attention should be given to the content of metabolizable protein and minerals, the latter usually having low absorption rates.

A promising strategy to increase animal productivity in the tropics is the adoption of intensive silvopastoral systems (ISS), a form of agroforestry which focuses on sustainable grazing management and integrates herbaceous forages, shrubs established in high densities (more than 10.000/ha), timber trees, and animals ${ }^{(5)}$. The benefits of ISS on productive parameters of the dairy herd have been adequately demonstrated ${ }^{(6)}$, but not enough attention has been given to the nutritional status of dairy cows in early lactation. As the adoption of ISS is increasing, it becomes important to determine in what proportion the nutritional requirements of animals are satisfied. The present study was carried out to estimate the nutritional balance of recently calved and early lactation crossbred dairy cows grazing on a Leucaena leucocephala-based ISS. 


\section{Materials and Methods}

The study was carried out at Hacienda El Chaco, located at the Department of Tolima, Colombia, at $04^{\circ} 29^{\prime} 07^{\prime \prime}$ North and $74^{\circ} 59^{\prime} 5^{\prime \prime}$ 'West. The farm is located in the tropical dry forest life zone ${ }^{(7)}$, with an altitude of 605 m.a.s.l and an average rainfall of $1200 \mathrm{~mm}$ per year ${ }^{(5)}$. During the experimental period, relative humidity was $70 \%$, average temperature was $26^{\circ} \mathrm{C}$, and monthly rainfall oscillated between 8.8 $\mathrm{mm}$ (June 2012) and $99.4 \mathrm{~mm}$ (February 2013).

Twelve crossbred (50\% Gyr x 50\% Holstein) dairy cows between 2 and 4 parturitions were evaluated both at calving (RC; day 0 from calving until 1-2 week postpartum) and at early lactation (EL; $42-50$ days after calving) during an eight-month experimental period starting in May 2012. Cows had $494 \pm$ $41,3 \mathrm{~kg}$ of body weight and 67 months of age.

When in the RC group, cows spent 4-5 d feeding their calves with colostrum and early lactation milk and from then on, they were milked twice daily and produced on average $14 \mathrm{~kg}$ of milk $\cdot \mathrm{d}^{-1}$. As part of the EL group, cows produced $17 \mathrm{~kg}$ of milk $\cdot \mathrm{d}^{-1}$. Throughout the experiment, cows grazed in an ISS with C. plectostachyus and L. leucocephala with $>10.000$ leucaena shrubs.ha ${ }^{-1}$ and Azadirachta indica, Albizia guachapele, and Tectona grandis trees planted in rows every $30 \mathrm{~m}$. In addition to grazing, cows received supplementation based on rice flour, mineral salt, corn silage, and commercial concentrate at a rate of $1.8,0.12,1.9$, and $2.6 \mathrm{~kg} \mathrm{DM} \cdot \mathrm{cow}^{-1}$, respectively.

Cows grazed ISS strips of 2000-3000 $\mathrm{m}^{2}$ divided by an electrical fence with $24 \mathrm{~h}$ occupation and $38 \mathrm{~d}$ recovery periods. Stocking rate in the ISS was $4.46 \mathrm{AU} \cdot \mathrm{ha}^{-1}$ ( $1 \mathrm{AU}=450 \mathrm{Kg}$ body weight) and the grazing pressure was $12.1 \mathrm{Kg}$ of DM per $100 \mathrm{Kg}$ body weight. Dry matter intake of ISS forages was estimated through quantification of DM offered and rejected ${ }^{(8)}$. Forage availability was estimated for $C$. plectostachyus and L. leucocephala in 15 out of 39 ISS paddocks. For C. plectostachyus, areas of high, medium, and low grass availability were measured within each paddock, assigning a grass availability score to 60 or more $0.25 \mathrm{~m}^{2}(50 \times 50 \mathrm{~cm})$ quadrats at randomly selected points ${ }^{(8)}$. The availability of $L$. leucocephala was estimated by measuring DM availability in one-lineal meter sections of high, medium, and low legume availability, where all edible forage was cut and weighed. As with the grass, 60 or more points were scored along the paddock. This procedure allowed quantification of DM availability per cow. Efficiency of forage utilization was estimated by quantifying forage refusals and expressing them as a percentage of forage available before grazing.

Whenever forage availability was estimated (six times during the experiment), forage samples were collected to perform chemical analyses. In turn, samples of supplements were collected twice during the study. Analyses carried out in these samples included the determination of calcium ${ }^{(9)}$ and phosphorus content $^{(10)}$, both by U.V - VIS atomic absorption spectrophotometry; total ash by direct incineration ${ }^{(11)}$; acid detergent fiber; neutral detergent fiber; ether extract ${ }^{(12)}$; crude protein by Kjeldahl $^{(13)}$ and gross energy content ${ }^{(14)}$. These analyses were carried out at the Laboratory of Chemical and Bromatological Analysis of the National University of Colombia, Medellín.

Nutrient intake was calculated from the nutrient content in forages and supplements and by n-alkanes estimates of DMI carried out in a parallel study in the same farm (Sossa, personal communication). Requirements of metabolizable protein (MP), metabolizable energy (ME) calcium and phosphorous of 
RC and EL cows were estimated with the help of the Cornell Net Carbohydrate and Protein System (CNCPS), Version 5.0.4 ${ }^{(15)}$. Nutritional balances were calculated as the difference between intake and requirements for cows fed the diet used in the farm and under simulated conditions of cows consuming only the ISS forages.

Data of nutritional balance, forage availability, DMI and forage use efficiency were evaluated following a repeated measurement analysis using the MIXED procedure of SAS ${ }^{(16)}$. In the case of the nutritional balance, the random effects were the animals and the fixed effects were the physiological status. For the rest of the variables, the random effects were the date of sampling and the fixed effect was the paddock. In terms of the forage chemical composition, an ANOVA was carried out using the GLM procedure of SAS, for which a completely randomized design was used.

\section{Results and Discussion}

Regarding the chemical composition of the diet, the protein content was almost three times greater in $L$. leucocephala (27\%) than in C. plectostachyus (9.4\%), highlighting the importance of the inclusion of this legume in the ISS (Table 1).

Table 1. Chemical composition (mean and SEM) of the diet available during the study to both $\mathrm{RC}$ and EL cows at Hacienda El Chaco

\begin{tabular}{|c|c|c|c|c|c|}
\hline Fraction & L. leucocephala & C. plectostachyus & Rice Flour & Concentrate & Corn Silage \\
\hline DM (\%) & 20 & 20 & 90.2 & 89.1 & 35 \\
\hline CP (\%) & $26 \pm 2.7$ & $9.9 \pm 1.7$ & $14.1 \pm 0.1$ & $18.5+0.5$ & $6.9+0.5$ \\
\hline NDF (\%) & $28.2 \pm 2.4$ & $75.1 \pm 1.2$ & $19.8 \pm 0.3$ & $25.5 \pm 0.8$ & $69.9 \pm 2.9$ \\
\hline ADF (\%) & $25.5 \pm 1.9$ & $41.7 \pm 0.7$ & $10.5 \pm 0.1$ & $15.7 \pm 1.5$ & $43.1 \pm 4.2$ \\
\hline EE (\%) & $2.75 \pm 0.6$ & $1.19 \pm 0.06$ & $20 . \overline{0} 4$ & $9 . \overline{07}$ & $1 . \overline{03}$ \\
\hline GE $\left(\mathrm{Cal} \cdot \mathrm{g}^{-1}\right)$ & $4640+103.1$ & $4317.5+17.7$ & $5203.5+103.9$ & $4484+69.3$ & $4280+140$ \\
\hline Ash (\%) & $8.9 \pm 0.7$ & $9 \pm 1$ & $9.2 \pm 0.8$ & $10.8 \pm 0.3$ & $8.1 \pm 1.2$ \\
\hline $\mathrm{Ca}(\%)$ & $1.5 \pm 0.3$ & $0.3 \pm 0.04$ & $0.1 \pm 0.06$ & $2.1 \pm 0.1$ & $0.2 \pm 0.04$ \\
\hline $\mathbf{P}(\%)$ & $0.2 \pm 0.05$ & $0.3 \pm 0.1$ & $2 \pm 0.1$ & $0.9 \pm 0.1$ & $0.2 \pm 0.04$ \\
\hline $\mathrm{Cu}\left(\mathrm{mg} \cdot \mathrm{Kg}^{-1}\right)$ & $21.3+15.4$ & $9+3.8$ & - & - & - \\
\hline $\mathrm{Fe}\left(\mathrm{mg} \cdot \mathrm{Kg}^{-1}\right)$ & $76.9+51.1$ & $184 . \overline{5} \pm 79$ & - & - & - \\
\hline Mn(\%) & $48+20.7$ & $28+\overline{3} .8$ & - & - & - \\
\hline $\mathbf{M g}\left(\mathbf{m g} \cdot \mathbf{K g}^{-1}\right)$ & $0.3+0.04$ & $0.1+0.01$ & - & - & - \\
\hline $\mathbf{K}\left(\mathbf{m g} \cdot \mathbf{K g}^{-1}\right)$ & $2.2 \pm 0.4$ & $1.9 \pm 0.5$ & - & - & - \\
\hline $\mathrm{Na}\left(\mathrm{mg} \cdot \mathbf{K g}^{-1}\right)$ & $42.1 \pm 41.9$ & $105.4 \pm 41.8$ & - & - & - \\
\hline $\mathrm{Zn}\left(\mathbf{m g} \cdot \mathbf{K g}^{-1}\right)$ & $23.5 \pm 3.1$ & $48.7 \pm 13.4$ & - & - & - \\
\hline $\begin{array}{l}\text { ME } \\
\text { (Mcal·KgDM) }\end{array}$ & 2.64 & 1.9 & 3.33 & 3.08 & 1.84 \\
\hline
\end{tabular}

$D M$ dry matter; $C P$ crude protein; $N D F$ neutral detergent fiber; $A D F$ acid detergent fiber; $E E$ ether extract; $G E$ gross energy.

The total diet (ISS + supplements) contained 14.3\% CP (dry matter basis), which should allow an adequate growth of ruminal bacteria and contribute to an efficient fermentation of structural carbohydrates while producing a significant amount of microbial protein ${ }^{(17)}$. Increases in dietary CP and 
calcium contents and reductions in NDF and ADF in response to the inclusion of Leucaena were similar to previous reports ${ }^{(2)}$. These changes are often accompanied by increased ruminal production of volatile fatty acids (propionic, butyric and acetic), supplying more energy to the ruminants ${ }^{(17)}$.

Content of ME was $1.9 \mathrm{Mcal} \cdot \mathrm{Kg}^{-1} \mathrm{DM}$ in C. plectostachyus, a value that is common in tropical grasses that have limited availability of energy ${ }^{(3)}$. Similar values were reported for this grass ${ }^{(18)}$. In turn, Leucaena provided $2.64 \mathrm{Mcal}$ of $\mathrm{ME} \cdot \mathrm{Kg}^{-1} \mathrm{DM}$, greater to what was reported (2.24 $\left.\mathrm{Mcal} \cdot \mathrm{Kg}^{-1} \mathrm{DM}\right)$ for Leucaena growing in Mexico ${ }^{(18)}$. Besides greater energy intake, the presence of Leucaena in the diet often leads to increased diet digestibility, due to greater specific gravity that leads to faster ruminal rate of passage $^{(3)}$ as L. leucocephala has a low content of NDF (29.1\%). Despite numerical variations, the content of CP, NDF, Ca, and P in ISS forages did not differ between the dry and rainy seasons $(\mathrm{p}>0,05)$, even though the $\mathrm{CP}$ content tended to be greater in the grass during the rainy season $(p=0,07)$ (Table 2).

Table 2. Chemical composition of $C$. plectostachyus and $L$. leucocephala samples at different climatological conditions (dry and rainy season)

\begin{tabular}{lcccccc}
\hline & \multicolumn{3}{c}{ L. leucocephala } & \multicolumn{3}{c}{ C. plectostachyus } \\
\hline & \multicolumn{3}{c}{ Season } & & \multicolumn{3}{c}{ Season } \\
\hline Fraction & $\begin{array}{c}\text { Dry } \\
(\boldsymbol{n}=\mathbf{5})\end{array}$ & $\begin{array}{c}\text { Rainy } \\
(\boldsymbol{n}=\mathbf{2})\end{array}$ & $\mathbf{p}$ & $\begin{array}{c}\text { Dry } \\
(\boldsymbol{n}=\mathbf{6})\end{array}$ & $\begin{array}{c}\text { Rainy } \\
(\boldsymbol{n}=\mathbf{2})\end{array}$ & $\mathbf{p}$ \\
$\mathrm{CP}(\%)$ & 24.94 & 28.35 & 0.17 & 9.28 & 11.75 & 0.07 \\
NDF (\%) & 27.78 & 29.25 & 0.54 & 75.23 & 74.85 & 0.73 \\
GE (cal $\left.\cdot \mathrm{g}^{-1}\right)$ & 4640 & - & & 4317.5 & - & \\
$\mathrm{Ca}(\%)$ & 1.55 & 1.36 & 0.54 & 0.28 & 0.32 & 0.41 \\
$\mathrm{P}(\%)$ & 0.19 & 0.26 & 0.08 & 0.32 & 0.37 & 0.50 \\
\hline
\end{tabular}

On average, estimated total DMI of RC and EL cows was $2.58 \%$ and $2.72 \%$ of their body weight (BW), respectively (Table 3). In turn, Mahecha et al. ${ }^{(19)}$ reported a DMI between 1.9 and $3.0 \%$ of BW in creole cows grazing ISS and receiving supplementation. Cows in early lactation exhibit low DMI, which gradually increases until two or three weeks beyond the peak of lactation ${ }^{(20)}$. Increased DMI is the result of increased nutritional requirements as the lactation progresses, and because high milk yielding dairy cows ruminate for long periods during the day. The estimated DMI for Leucaena was $2.05 \pm 0.47$ and $2.48 \pm 0.39 \mathrm{Kg} \mathrm{DM} / \mathrm{d}$ for RC and EL cows, respectively (Table 3).

These intakes appear to be lower than those reported by Valdivia, of $2.6 \mathrm{Kg} \mathrm{DM} \cdot \mathrm{d}^{-1}$ in crossbred cows with energy supplementation $^{(21)}$. It is possible that greater intake of Leucaena would occur in cows when grazing on a greater density ISS or at lower stocking rates ${ }^{(22)}$. Greater dietary proportion $(31.2 \%)$ of Leucaena was reported by Cuartas et al., in beef steers receiving no supplementation, suggesting that there was a substitution effect in the animals evaluated in this study ${ }^{(2)}$. However, it is clear that animals preferred to consume Leucaena over star grass. Intake of Leucaena represented $27.5 \%$ of the total forage intake of RC cows, while that of EL cows represented $29.36 \%$ of total forage intake. As shown in Table 3, RC cows had lower intake (Kg DM. $\left.\mathrm{d}^{-1} \cdot \mathrm{cow}^{-1}\right)$ of star grass (5.40) compared to the EL cows (5.99). In turn, dietary supplements were administrated at a constant rate during the experimental period to both $\mathrm{RC}$ and EL cows, and hence, there were no differences in their intake. 
Table 3. Estimated dry matter intake (average and SEM) of forages and supplements of cows at Hacienda El Chaco

\begin{tabular}{|c|c|c|c|c|}
\hline \multirow[t]{2}{*}{ Ingredients } & \multicolumn{2}{|c|}{ RC Cows } & \multicolumn{2}{|c|}{ EL Cows } \\
\hline & $\begin{array}{c}\text { Feed } \\
\left(\mathrm{Kg} \mathrm{DM}^{-} \operatorname{cow}^{-1} \cdot \mathbf{d}^{-1}\right)\end{array}$ & $\begin{array}{c}\% \text { of Forage } \\
\text { DM }\end{array}$ & $\begin{array}{c}\text { Feed } \\
\left(\mathrm{Kg} \mathrm{DM}^{\cdot} \operatorname{cow}^{-1} \cdot \mathrm{d}^{-1}\right)\end{array}$ & $\begin{array}{c}\% \text { of Forage } \\
\text { DM }\end{array}$ \\
\hline C. plectostachyus & $5.4 \pm 1.04$ & 72.48 & $5.99 \pm 0.62$ & 70.64 \\
\hline L. leucocephala & $2.05 \pm 0.47$ & 27.52 & $2.48+0.39$ & 29.36 \\
\hline \multirow[t]{2}{*}{ Total } & 7.45 & 100 & 8.48 & 100 \\
\hline & & $\begin{array}{c}\text { \% of } \\
\text { Suplements } \\
\text { DM }\end{array}$ & & $\begin{array}{c}\text { \% of } \\
\text { Suplements } \\
\text { DM }\end{array}$ \\
\hline $\begin{array}{l}\text { Comercial } \\
\text { Concentrate }\end{array}$ & 2.6 & 49 & 2.5 & 50 \\
\hline Corn Silage & 1.2 & 22.6 & 1.0 & 20 \\
\hline Rice Flour & 1.5 & 28.3 & 1.5 & 30 \\
\hline Total & 5.3 & 100 & 5.0 & 100 \\
\hline Total DMI & 12.75 & & 13.48 & \\
\hline $\begin{array}{l}\text { Forage/Concentrate } \\
\text { Ratio }\end{array}$ & $2.8: 1$ & & $3.4: 1$ & \\
\hline
\end{tabular}

The EL cows consumed more gross energy (GE), CP, Ca, P, and NDF from forages than the RC cows. About $60 \%$ and $64 \%$ of the consumed CP came from ISS forages for both RC and EL cows, while $50 \%$ of the CP supplied by the forages came from Leucaena. The GE supplied by the forages was greater than that provided by the supplements (59\% in RC and 61\% in EL). NDF was supplied in greater amounts by the forages in both RC and EL ( $72 \%$ \& $76 \%$ respectively) (Table 4$)$.

Table 4. Nutrient and DM intake from forages and supplements at Hacienda El Chaco for RC and EL cows

\begin{tabular}{|c|c|c|c|c|c|c|c|}
\hline Feeds & $\underset{(n=12)}{\text { PS }}$ & 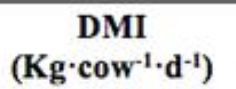 & $\begin{array}{c}\text { GE } \\
\left(\text { Mcal }^{-1} \mathbf{d}^{-1}\right)\end{array}$ & $\underset{\left(g \cdot d^{-1}\right)}{C P}$ & $\underset{\left(\mathrm{g} \cdot \mathrm{d}^{-1}\right)}{\mathrm{Ca}}$ & $\begin{array}{c}P \\
\left(g \cdot d^{-1}\right)\end{array}$ & $\begin{array}{c}\text { FDN } \\
\left(\mathrm{g} \cdot \mathrm{d}^{-1}\right)\end{array}$ \\
\hline \multirow{2}{*}{ C. plectostachyus } & $\mathrm{RC}$ & $5.30 \mathrm{~b}$ & $22.8 \mathrm{~b}$ & $557.12 \mathrm{~b}$ & $15.9 \mathrm{~b}$ & $18.28 \mathrm{~b}$ & $3674.9 \mathrm{~b}$ \\
\hline & EL & $5.99 \mathrm{a}$ & $25.8 \mathrm{a}$ & 629.9 a & $17.98 \mathrm{a}$ & 20.67 a & $4497.4 \mathrm{a}$ \\
\hline \multirow{2}{*}{ L. leucocephala } & RC & $2.09 \mathrm{~b}$ & $9.7 \mathrm{~b}$ & $556.78 \mathrm{~b}$ & $28.42 \mathrm{~b}$ & $4.70 \mathrm{~b}$ & $595.96 \mathrm{~b}$ \\
\hline & EL & $2.40 \mathrm{a}$ & $11.15 \mathrm{a}$ & 640.47 a & $32.69 \mathrm{a}$ & $5.40 \mathrm{a}$ & $685.54 \mathrm{a}$ \\
\hline \multirow{2}{*}{$\begin{array}{l}\text { Comercial } \\
\text { Concentrate }\end{array}$} & $\mathrm{RC}$ & $2.48 \mathrm{a}$ & $11.1 \mathrm{a}$ & $458.8 \mathrm{a}$ & $52.08 \mathrm{a}$ & $22.32 \mathrm{a}$ & $632.4 \mathrm{a}$ \\
\hline & EL & $2.48 \mathrm{a}$ & $11.1 \mathrm{a}$ & $459.41 \mathrm{a}$ & $52.15 \mathrm{a}$ & $22.35 \mathrm{a}$ & $633.3 \mathrm{a}$ \\
\hline \multirow{2}{*}{ Corn Silage } & $\mathrm{RC}$ & $1.114 \mathrm{a}$ & $4.7 \mathrm{a}$ & $76.87 \mathrm{a}$ & $2.22 \mathrm{a}$ & $2.22 \mathrm{a}$ & $778.8 \mathrm{a}$ \\
\hline & EL & $1.038 \mathrm{~b}$ & $4.4 \mathrm{~b}$ & $71.64 \mathrm{~b}$ & $2.07 \mathrm{~b}$ & $2.07 \mathrm{~b}$ & $725.8 \mathrm{~b}$ \\
\hline \multirow{2}{*}{ Rice Flour } & $\mathrm{RC}$ & $1.35 \mathrm{a}$ & $7.0 \mathrm{a}$ & $191.4 \mathrm{a}$ & $1.35 \mathrm{a}$ & $27.15 \mathrm{a}$ & $268.8 \mathrm{a}$ \\
\hline & EL & $1.44 \mathrm{a}$ & $7.5 \mathrm{a}$ & 203.98 a & $1.44 \mathrm{a}$ & $28.93 \mathrm{a}$ & $286.4 \mathrm{a}$ \\
\hline \multirow{2}{*}{ Total } & $\mathrm{RC}$ & 12.33 & 55.3 & 1840.97 & 99.97 & 74.67 & 5950.8 \\
\hline & EL & 13.351 & 59.95 & 2005.4 & 106.33 & 79.42 & 6828.4 \\
\hline
\end{tabular}

Means with the same letter are not significantly different $(p<0.05)$.

Availability of C. plectostachyus DM in the daily grazing paddocks ranged from 1279 to $2163 \mathrm{Kg}$ DM.ha' 
${ }^{1}$ and did not vary statistically during the experimental period $(\mathrm{p}<0.05)$ (Figure 1). These values are similar to those reported by Peniche-González et al. ${ }^{(18)}$, who found an availability of $1692 \pm 766$ and $1797 \pm 617.7$ $\mathrm{Kg} \mathrm{DM} \cdot \mathrm{ha}^{-1}$ for stargrass in dry and rainy seasons, respectively in an ISS in Mexico. On the other hand, $L$. leucocephala availability differed among grazing strips (82 to $939 \mathrm{Kg} \mathrm{DM} \cdot \mathrm{ha}^{-1}$ ). Such reduction occurred in only two of the grazing strips with waterlogging problems (Figures 1 and 2). In the region where the study took place, forages available to grazing animals are native and introduced grasses such as Hyparrhenia rufa, Paspalum spp., and Bothriochloa pertusa, most of low quality and availability during the dry season. Along with increased forage availability, the shade provided by the trees in ISS contributes to reduced stress associated with high ambient temperatures for both forage and animals. In forages, lack of shade reduces the growth and the nutritional quality, being associated with reduced nitrogen content and diet digestibility ${ }^{(23)}$. In this experiment, when the availability of Leucaena decreased, that of star grass increased, possibly due to reduced competition. High diurnal temperatures and low precipitation could have reduced grass yields in the current study.

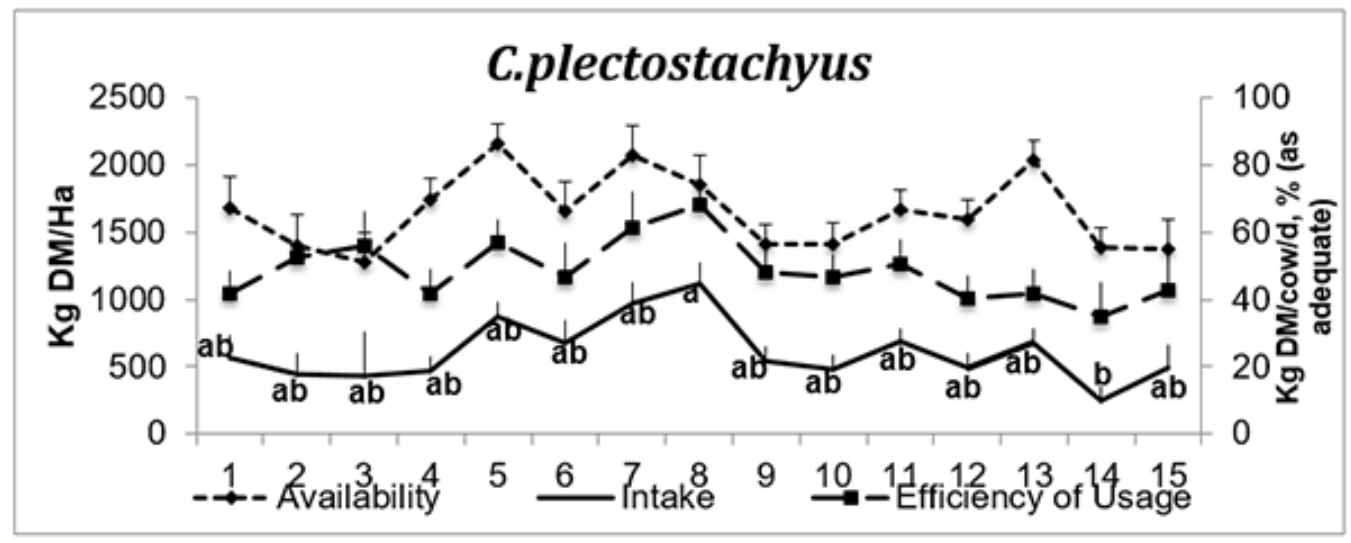

Figure 1. Variation of ISS forage availability $\left(\mathrm{kg} \mathrm{DM} \cdot \mathrm{ha}^{-1}\right)$, refusal $\left(\mathrm{Kg} \mathrm{DM} \cdot \mathrm{cow}^{-1} \cdot \mathrm{d}^{-1}\right)$, and efficiency of usage (\%) of C. plectostachyus.

Means with the same letter are not significantly different $(\mathrm{p}<0.05)$.

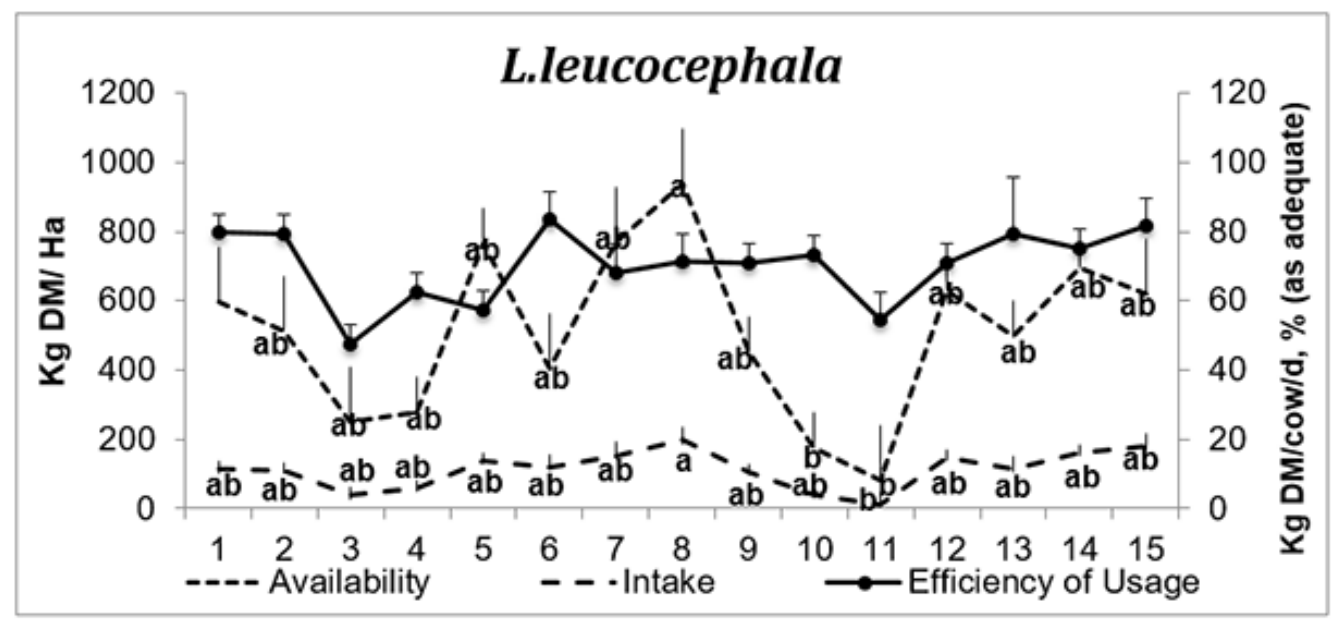

Figure 2. Variation of ISS forage availability $(\mathrm{kg} \mathrm{DM} \cdot \mathrm{ha}-1)$, refusal $\left(\mathrm{Kg} \mathrm{DM} \cdot \operatorname{cow}^{-1} \cdot \mathrm{d}^{-1}\right)$, and efficiency of usage (\%) of L. leucocephala.

Means with the same letter are not significantly different $(p<0.05)$ 
Table 5. Nutritional requirements and balance of $\mathrm{RC}$ and $\mathrm{EL}$ Cows consuming the whole diet: C. plectostachyus, L. leucocephala, and supplements at Hacienda El Chaco

\begin{tabular}{|c|c|c|c|c|}
\hline \multicolumn{5}{|c|}{ Nutritional balance of recently calved cows } \\
\hline Requirements & ME (Mcal-d $\left.\mathbf{d}^{-1}\right)$ & $\operatorname{MP}\left(g \cdot d^{-1}\right)$ & $\mathrm{Ca}\left(\mathrm{g} \cdot \mathrm{d}^{-1}\right)$ & $\mathbf{P}\left(\mathrm{g} \cdot \mathbf{d}^{-1}\right)$ \\
\hline Total Required & 27.81 & 1119.8 & 31.74 & 26.25 \\
\hline Total Supplied & 29.37 & 1339.8 & 47.25 & 49.42 \\
\hline Balance & $1.55 \mathrm{a}$ & $220.0 \mathrm{a}$ & $15.5 \mathrm{a}$ & $23.16 \mathrm{a}$ \\
\hline \multicolumn{5}{|c|}{ Nutritional balance of early lactation cows } \\
\hline Total Required & 32.19 & 1374.7 & 35.41 & 31.25 \\
\hline Total Supplied & 31.73 & 1460.3 & 54.91 & 52.50 \\
\hline Balance & $-0.45 \mathrm{~b}$ & $85.6 \mathrm{~b}$ & $19.50 \mathrm{a}$ & $21.25 \mathrm{~b}$ \\
\hline
\end{tabular}

Means with the same letter are not significantly different $(p<0.05)$

The grazing efficiency was greater for leucaena (70.3\%) than for star grass (48.7\%) (Fig 1-2). This fact was consistently observed as the cows moved from one paddock to the other as Leucaena was highly selected due to its palatability and easy access to the animal. Star grass was partly rejected as cows refused to eat from places that had received urine or feces, had been lied upon or stepped on. With regard to the high stocking rate observed in this study, similar values were reported by Murgueitio et al. ${ }^{(6)}$ in ISS with Leucaena (10000 plants· ha $\left.{ }^{-1}\right)$. The estimated nutrient requirements of cows at Hacienda El Chaco, using CNCPS Version 5.0.4 and the NB of cows receiving the whole diet indicated that RC cows would have a positive metabolizable energy balance, while EL cows would have a negative energy balance (1.55 and $-0.45 \mathrm{Mcal} \cdot \mathrm{d}^{-1}$, respectively) (Table 5).

Table 6. Nutritional requirements and balance of $\mathrm{RC}$ and EL cows at a scenario of consuming only ISS forages: C. plectostachyus and L. leucocephala at Hacienda El Chaco

\begin{tabular}{|c|c|c|c|c|}
\hline \multicolumn{5}{|c|}{ Nutritional balance of recently calved cows } \\
\hline Requirements & ME (Mcal-d $\left.\mathbf{d}^{-1}\right)$ & $\operatorname{MP}\left(g \cdot d^{-1}\right)$ & $\mathrm{Ca}\left(\mathrm{g} \cdot \mathrm{d}^{-1}\right)$ & $P\left(g \cdot d^{-1}\right)$ \\
\hline Total Required & 24.52 & 991 & 28 & 21 \\
\hline Total Supplied & 20.73 & 859 & 24 & 19 \\
\hline Balance & -3.79 & -132 & -4 & -2 \\
\hline \multicolumn{5}{|c|}{ Nutritional balance of early lactation cows } \\
\hline Total Required & 26.15 & 1184 & 30 & 26 \\
\hline Total Supplied & 23.89 & 1183 & 27 & 23 \\
\hline Balance & -2.26 & -1 & -3 & -3 \\
\hline
\end{tabular}

This result was associated to the greater energy demand of EL cows for milk production. Intake of ISS forages provided almost 54.4 and $58.5 \%$ of ME, while supplements provided 45.6 and $41.4 \%$ for RC and EL, respectively. Overall, energy availability was not likely to limit neither milk production nor initiation of reproductive activity. For cows around 350 and $400 \mathrm{Kg}$ of BW, daily maintenance energy requirements fluctuated between 9.55 and $10.75 \mathrm{Mcal} \cdot \mathrm{d}^{-1}$. Lactation energy requirements depend basically on milk volume and composition ${ }^{(24)}$. On average, milk from EL cows had $3.21 \%$ fat and $3 \%$ protein. MAFF calculated that the energy needed to produce one liter of milk with this composition is approximately $1.12 \mathrm{Mcal} \mathrm{ME}^{(25)}$. For the cows of this study, producing $17 \mathrm{~L}$ of milk on average, total 
ME requirements were $27.81 \mathrm{Mcal} \cdot \mathrm{d}^{-1}$.

Mertens ${ }^{(26)}$ suggested adult cows at early lactation should consume NDF at almost $0.87-1.0 \%$ of BW. In this study, crossbred cows had an NDF intake of 1.2 and $1.39 \%$ of BW for RC and EL cows, respectively. Similarly, Vazquez \& Smith ${ }^{(4)}$ reported an NDF intake of $1.32 \pm 0.25 \%$ of the BW in dairy cows. This could be due to the high DMI of star grass, which contributed with 61 to $65 \%$ of all the $\mathrm{NDF}$ of the diet in RC and EL cows. On average, the diet contained 52\% of NDF. There was a positive balance in metabolizable protein (RC: $220 \mathrm{~g} \cdot \mathrm{d}^{-1}, \mathrm{EL}: 85.6 \mathrm{~g} \cdot \mathrm{d}^{-1}$ ). As the total supplied protein exceeded the RC and EL requirements, cows needed to excrete surplus protein. During this process, energy is consumed in the liver to convert ammonia to urea, which is excreted through the urine ${ }^{(1)}$. However, it is possible that part of this surplus passed the rumen as undegraded protein, as Leucaena contains tannins that protect PC from excessive rumen degradation ${ }^{(27)}$. Forages contributed with most of the CP, supplying 60.5 and $63.3 \%$ for RC and EL cows, respectively. The considerable N excretion in both RC and EL cows implies high nutrient recycling in ISS, with increased grass productivity. In terms of minerals, a positive balance was estimated for RC and EL cows, being 15.5 and $19.5 \mathrm{~g} \cdot \mathrm{d}^{-1}$ for Ca and 23.16 and $21.25 \mathrm{~g} \cdot \mathrm{d}^{-1}$ for $\mathrm{P}$, respectively. Minerals are commonly found in low quantities in forages, yet in this study, sufficient amounts were supplied by the whole diet. The nutrient requirements were also estimated if cows were only to consume ISS forages (Table 6). For this purpose, RC cows (494 $\mathrm{Kg}$ of $\mathrm{BW}$ ) were assumed to produce 10 liters of milk $\cdot \mathrm{d}^{-1}$ and consume $10.5 \mathrm{Kg}$ of star grass and leucaena, whereas EL cows, weighing $488 \mathrm{Kg}$ of BW, were assumed to produce 12 liters of milk $\cdot \mathrm{d}^{-1}$ and consume $12.8 \mathrm{Kg}$ of DM. A greater negative NB was predicted for RC cows, which would lead to a loss of $0.5 \mathrm{~kg}$ of $\mathrm{BW} \cdot \mathrm{d}^{-1}$ and their diet would contain $14.7 \%$ of $\mathrm{CP}$ and $1.97 \mathrm{Mcal} \mathrm{EM} \mathrm{Kg} \cdot \mathrm{DM}^{-1}$. In turn, it was predicted that EL cows would also be in negative balance, but this would only generate a loss of $0.3 \mathrm{Kg}$ of $\mathrm{BW} \cdot \mathrm{d}^{-1}$. In both cases, milk production would be greater than that reported for the Tolima region when cows only graze forages $\left(6.1\right.$ liters $\left.\cdot \mathrm{d}^{-1} \cdot \mathrm{cow}^{-1}\right)$. Despite decreased milk production under this no supplementation scenario, the economic returns per cow would be similar than the one observed with supplemented cows, as the dietary inclusion of corn silage and rice flour increases the costs of milk production. Given that on a forage-only scenario, ISS forages would provide between $84 \%$ and $91 \%$ of the ME required, and $86 \%$ of MP required by RC and EL cows, respectively, there is the need to increase DMI by these animals. A strategy to increase intake by RC and EL cows would be reducing the stocking rate to increase DM offer from shrub fodder and forages ${ }^{(3,22)}$ or increasing the area of the daily grazing strip, while reducing the usage of supplements.

Regarding total non-fiber carbohydrates (NFC), the concentration found in the forage-only diet was 17 and $18 \%$ for RC and EL cows, respectively. This value is lower than the ideal NFC concentration of 38$40 \%$, which means that there is a restriction of potentially fermentable NFC in the rumen that could reduce the speed of rumen DM degradation.

\section{Conclusions}

ISS forages as C. plectostachyus and L. leucocephala can supply considerable amounts of ME, MP, and minerals (calcium and phosphorous) to both RC and EL cows. Under the current nutritional 
management at the Hacienda El Chaco, RC and EL cows consuming ISS and supplements have positive nutrient (protein, calcium and phosphorus) and energy balances.

Even though negative balances were estimated if high producing cows consumed only ISS forages, the remaining amounts of ME, MP, and minerals could be provided by formulating low cost supplements and based on local feeds.

Balances of protein and phosphorus could be adjusted even further to reduce the excretion of these nutrients to the environment and to reduce the costs in feeds such as concentrated and silages.

It is recommended that the DMI of RC and EL cows must be monitored both during the dry and rainy season to prevent deficiencies and illnesses.

\section{Acknowledgements}

The authors would like to thank the Mejia Fortich Family, owners of Hacienda El Chaco, who generously allowed us to conduct this study in their farm. Also, special thanks to CIPAV staff for their logistical support. This study was funded by COLCIENCIAS and the Patrimonio Autónomo Fondo Nacional de Financiamiento para la Ciencia, la Tecnología y la Innovación, Francisco José de Caldas and FEDEGAN-FNG (Grant 0527-2011).

\section{References}

1. NRC. Nutrient Requierements of Dairy Cattle. 6th rev. e. Washington D.C: National Academy Press; 1989.

2. Cuartas CA, Naranjo JF, Tarazona AM, Barahona R. Uso de la energía en bovinos pastoreando sistemas silvopastoriles intensivos con Leucaena leucocephala y su relacion con el desempeño animal. Rev CES Med Zootec. 2013;8(1):70-81.

3. Barahona R, Sánchez S. Limitaciones físicas y químicas de la digestibilidad de pastos tropicales y estrategias para aumentarla. Rev Corpoica. 2005;6(1):69-82.

4. Vazquez OP, Smith TR. Factors affecting pasture intake and total dry matter intake in grazing dairy cows. J Dairy Sci. 2000;83(2301-2309).

5. Tarazona AM, Ceballos MC, Cuartas CA, Naranjo JF, Murgueitio E, Barahona R. The relationship between nutritional status and bovine welfare associated with adoption of intensive silvopastoral systems in tropical conditions. In: FAO, editor. Enhancing animal welfare and farmer income through strategic animal feeding - Some Case Studies. Italy; 2013. p. 69-78.

6. Murgueitio E, Chará J, Barahona R, Cuartas C, Naranjo J. Los sistemas silvopastoriles intensivos (SSPi), herramienta de mitigación y adaptación al cambio climático. Trop Subtrop Agroecosystems. 2014;17(3):501-7.

7. Holdridge L., Grenke W., Hatheway T, Liang T, Tosi J. Forest environments in tropical life zones, a pilot study. Pergamon P. Oxford; 1971. 747 p.

8. Haydock KP, Shaw NH. The comparative yield method for estimating dry matter yield of pasture. Aust J 
Exp Agric Anim Husb. 1975;15:299-304.

9. Instituto Colombiano de Normas Técnicas y Certificación (ICONTEC). NTC 5151. Alimentos para animales. Determinación del contenido de calcio, cobre, hierro, magnesio, manganeso, potasio, sodio y zinc. Método usando espectrometría de absorción atómica. Bogotá D.C; 2003.

10. Instituto Colombiano de Normas Técnicas y Certificación (ICONTEC). NTC 4981. Alimentos para animales. Determinación del contenido de fósforo. Método espectrofotométrico. Bogotá D.C; 2001.

11. Association Of Official Analytical Chemists (AOAC). Official Method 942.05. Determination of Ash in Animal Feed. In: Official Methods of Analysis of AOAC International. 18th editi. Gaithersburg, MD, USA: AOAC International; 2005. p. 8.

12. Instituto Colombiano de Normas Técnicas y Certificación (ICONTEC). NTC 668. Alimentos y Materias Primas. Determinacion de los contenidos de grasa y fibra cruda. Bogotá D.C; 1973.

13. Instituto Colombiano de Normas Técnicas y Certificación (ICONTEC). NTC 4657. Alimento para animales. Determinación del contenido de proteína cruda. Método Kjeldahl. Bogotá D.C; 1999.

14. International Organization for Standardization. Animal feeding stuffs, animal products, and faeces or urine - Determination of gross calorific value - Bomb calorimeter method. ISO 9831. Geneve, Switzerland.; 1998.

15. Fox DG, Tylutki TP, Tedeschi LO, VAn-Amburgh ME, Chase LE, Pell AN, et al. The net carbohydrate and protein system for evaluating herd nutrition and nutrient excretion: Model Documentation. Mimeo No. . Ithaca, NY: Animal Science Department, Cornell University; 2000.

16. SAS Institute. S.A.S User guide, version 8.0. Cary, NC; 1999.

17. Ramírez-Avilés L, Ku-Vera JC, Alayón-Gamboa JA. Follaje de árboles y arbustos en los sistemas de producción bovina de doble propósito. Arch Latinoam Prod Anim. 2007;15(1):251-64.

18. Peniche-González IN, González-López ZU, Aguilar-Pérez CF, Ku-Vera JC, Ayala-Burgos AJ, SolorioSánchez FJ. Milk production and reproduction of dual-purpose cows with a restricted concentrate allowance and access to an association of Leucaena leucocephala and Cynodon nlemfuensis. J Appl Anim Res [Internet]. Taylor \& Francis; 2014 Jan 16 [cited 2014 Mar 27];1-7. Available from: http://www.tandfonline.com/doi/abs/10.1080/09712119.2013.875902

19. Mahecha L, Rosales M, Molina E, Duran C V, Molina CH. Consumo de pasto estrella africana (Cynodon plectostachyus) y Leucaena (Leucaena leucocephala) en un sistema silvopastoril. Pasturas Trop. 2000;22(1):5.

20. Garnsworthy PC, Topps JH. The effect of body condition of dairy cows at calving on their food intake and performance when given complete diets. Anim Prod. 1982;44:347-53.

21. Valdivia S V. Metabolismo del nitrógeno y función ruminal en vacas cruzadas Bos taurus x Bos indicus en un sistema silvopastoril con Leucaena leucocephala. Universidad Autónoma de Yucatán.; 2006. [PhD Thesis] Universidad Autónoma de Yucatán, Mérida, México pp $189 . \quad$ In: [http://148.209.1.31/opac/sisbiuadyOPAC.php\#]

22. Bacab-Pérez HM, Solorio-Sánchez J. Oferta y consumo de forraje y producción de leche en ganado de doble propósito manejado en sistemas silvopastoriles en Tepalcatepec, Michoacán. Trop Subtrop Agroecosyst. 2011;13:271-8.

23. Allard G, Nelson CJ, Pallardy SG. Shade effects on growth of tall fescue. II. Leaf gas exchange characteristics. Crop Sci. 1991;31:167-72. 
24. Moran J. Tropical Dairy Farming. Feeding Management for Small Holder Dairy Farmers in Humid Tropics. Australia: Landlinks Press; 2005. 313 p.

25. MAFF. Energy allowances and feeding systems for ruminants. London, England; 1984.

26. Mertens DR. Análise da fibra e sua utilização na avaliação de alimentos e formulação de rações. In: Simpósio Internacional de Rumiantes. Lavras: Lavras, UFLA; 1992. p. 188-219.

27. Barahona R, Lascano C, Narvaez N, Owen E, Morris P, Theodorou M. In Vitro degradability of mature and inmature leaves of tropical forage legumes differing in condenced tannin and non-starch polysaccharide content and composition. J Sci Food Agric. 2003;83:12561266. 